\title{
Evaluation of celiac artery blood flow in children with chronic active gastritis
}

\author{
Kronik aktif gastritli çocuklarda çölyak arter kan akımının değerlendirilmesi
}

\author{
Ulas Emre Akbulut, Mehmet Burak Ozkan, Ishak Abdurrahman Isik, Atike Atalay
}

Gönderilme tarihi:20.04.2020

Kabul tarihi:17.07.2020

\begin{abstract}
Purpose: Knowledge on gastric blood flow in children with chronic gastritis is scarce. In this study, we aimed to evaluate hemodynamic changes of the celiac artery (CA), in children with chronic gastritis assessed using trans-abdominal duplex Doppler ultrasonography.

Materials and methods: We examined 36 children (group 1) with chronic active gastritis (diagnosed by endoscopy and histology) and 28 asymptomatic control children (group 2) with duplex Doppler ultrasonography. Children with chronic gastritis were classified again according to the severity of inflammation and the presence of Helicobacter pylori infection. Mean peak systolic velocity (PSV), enddiastolic velocity (EDV), resistive index $(\mathrm{RI})$, and pulsatility index $(\mathrm{PI})$ of the CA were compared.

Results: The mean PSV and the mean EDV were significantly lower in patients than in controls $(p<0.001)$. The mean PI and the mean RI were significantly higher in the patient group than in the controls $(p<0.001)$. In addition, mean PSV was significantly lower in patients with $\mathrm{H}$. pylori than in patients without $\mathrm{H}$. pylori $(p<0.05)$. Conclusions: In this first study, children with chronic active gastritis were associated with a decrease in CA flow velocities that could be seen on Doppler ultrasonography. Doppler ultrasonography can be used in preliminary diagnostic work-up before further invasive tests.
\end{abstract}

Key words: Doppler ultrasonography, celiac artery, gastritis, children, helicobacter pylori.

Akbulut UE, Ozkan MB, Isik IA, Atalay A. Evaluation of celiac artery blood flow in children with chronic active gastritis. Pam Med J 2021;14:21-29.

Özet

Amaç: Kronik gastritli çocuklarda mide kan akımı hakkında bilgi bulunmamaktadır. Bu çalışmada kronik gastritli çocuklarda transabdominal dupleks Doppler ultrasonografi ile çölyak arterin hemodinamik değişikliklerini değerlendirmeyi amaçladık.

Gereç ve yöntem: Kronik aktif gastritli (endoskopi ve histoloji tanısı alan) 36 çocuğu (grup 1) ve 28 asemptomatik sağlıklı çocuğu (grup 2) dupleks Doppler ultrasonografi ile inceledik. Kronik gastritli çocuklar Helicobacter pylori enfeksiyonunun varlığına ve inflamasyonun şiddetine göre tekrar sınıflandırıldı. Çölyak arterin uç diyastolik hızı, ortalama pik sistolik hızı, pulsatilite indeksi ve rezistif indeksi karşılaştırıldı.

Bulgular: Grup 1'de ortalama pulsatilite indeksi ve ortalama rezistif indeksi anlamlı olarak daha yüksekken $(p<0.001)$, grup 1'de ortalama pik sistolik hızı ve ortalama uç diyastolik hızı kontrollerden $(p<0.001)$ anlamlı olarak daha düşüktü. Ayrıca, ortalama pik sistolik hızı Helicobacter pylori olmayan hastalarda Helicobacter pylori hastalarına göre anlamlı olarak daha yüksekti $(p<0.05)$.

Sonuç: Bu çalışmada, kronik aktif gastritli çocukların çölyak arter kan akımında azalma olduğu gösterilmiştir. Doppler ultrasonografi gastrit şüphesi olan çocuklarda daha ileri invaziv testlerden önce ilk basamak tanı incelemesinde kullanılabilir.

Anahtar kelimeler: Doppler ultrasonografi, çölyak arter, gastrit, çocuk, helikobakter pilori.

Akbulut UE, Özkan MB, Işık IA, Atalay A. Kronik aktif gastritli çocuklarda çölyak arter kan akımının değerlendirilmesi. Pam Tıp Derg 2021;14:21-29.

\footnotetext{
Ulas EmreAkbulut, MD., Assoc. Prof. University of Health Sciences, Antalya Education and Research Hospital, Dept. of Pediatric Gastroenterology Hepatology and Nutrition, Antalya, Turkey, e-mail: ulasemre@hotmail.com (orcid.org/0000-0002-5098-4787) (Corresponding Author)

Mehmet Burak Ozkan, MD. University of Health Sciences, Antalya Education and Research Hospital, Dept. of Pediatric Radiology, Antalya, Turkey, e-mail: bozkan04@gmail.com (orcid.org/0000-0003-4672-0671)

Ishak Abdurrahman Isik, MD. University of Health Sciences, Antalya Education and Research Hospital, Dept. of Pediatric Gastroenterology Hepatology and Nutrition, Antalya, Turkey, e-mail: ishakisik02@yahoo.com.tr (orcid.org/0000-0001-8745-8353)

Atike Atalay, MD. University of Health Sciences, Antalya Education and Research Hospital, Dept. of Pediatric Gastroenterology Hepatology and Nutrition, Antalya, Turkey, e-mail: atike_akaslan@yahoo.com (orcid.org/0000-0001-8909-2746)
} 


\section{Introduction}

Chronic gastritis is a prevalent disease in the general population and may progress insidiously. Although more widespread in adults, it is also a clinically significant disease in children. The occurrence of chronic gastritis in children has been reported between $2 \%$ and $8 \%$ in different international studies [1]. However, the classic symptoms like aggravation of epigastric pain after meal are present in only a minority of patients. So the most important factor in the early diagnosis of chronic gastritis is clinical suspicion [2].

Due to its sensitivity and specificity, esophagogastroduodenoscopy (EGD) is a gold standard method for evaluating mucosal lesions of the upper gastrointestinal system [3]. However, as an invasive method EGD should be performed in selected patients in the presence of alarm symptoms like weight lost, failure to thrive, persistent vomiting and/or diarrhea, unexplained anemia, dysphagia or gastrointestinal bleeding as recommended by The European Society for Paediatric Gastroenterology Hepatology and Nutrition (ESPGHAN) and The European Society of Gastrointestinal Endoscopy (ESGE) guidelines [4]. Non-invasive methods are, therefore, needed to evaluate mucosal lesions of the gastrointestinal system.

Gastric mucosal blood flow has some important functions such as supplementation of nutrients and oxygen, transport of hydrogen ions derived from hydrochloric acid and protection of mucosa [5]. Any decrease in the blood supply may result in mucosal ischemia and damage $[5,6]$. Previous studies have demonstrated decreased gastric mucosal blood supply in patients with chronic gastritis [7]. In addition, hemodynamic instability in larger vessels such as the celiac artery (CA) has also been observed in patients with chronic gastritis [8].

The aim of this study was to evaluate the hemodynamic changes of the CA by transabdominal duplex Doppler ultrasonography in children with chronic gastritis.

\section{Materials and methods}

\section{Study design and patients}

This prospective study was performed at a tertiary center in Turkey. The study was carried out after receiving approval from the local ethics committee and informed parental consent in accordance with the Declaration of Helsinki.

All the endoscopic investigations were performed by pediatricendoscopists (U.E.A., I.A.I. and A.A.) in the endoscopy unit using an EG-530WR (Fuji Film, Tokyo, Japan) device. Endoscopic evaluation of gastritis had been done according to the Sydney System [9, 10]. Presence and severity (mild, moderate or severe) of gastritis had been evaluatedendoscopically for each patient. Two biopsies from the stomach (antrum and corpus) and two from the first and second part of the duodenum were taken during endoscopy. The biopsy specimens were fixed in $10 \%$ formalin and sent to the pathology department of our hospital. After hematoxylin and eosin (H\&E) staining of the specimens histopathological findings were also evaluated according to the Sydney System [9]. Depending on the intensity of lymphocyte and plasma cells in the lamina propria of gastric mucosa, inflammation was classified as mild, moderate, or severe. Helicobacter pylori (H. pylori) infection was detected by Giemsa staining at antral biopsy and by rapid urease test.

Thirty-six children with gastritis (Group 1) and 28 age- and sex-matched healthy children (Group 2) were included in the study. Group 1 was further divided into two subgroups according to the endoscopical and histopathological severity of the gastritis. Mild gastritis group (Group 1a) consisted of 14 patients and moderate and severe gastritis group (Group 1b) of 22 patients. Group 1 patients also classified according to the $\mathrm{H}$. pylori infection. 19 patients with $\mathrm{H}$. pylori infection consisted group $1 \mathrm{c}$ and 17 patients without $H$. pylori infection group 1d. Subjects with previous known organic diseases (such as inflammatory bowel disease, celiac disease, or hepatitis) were not included in the study.

\section{Doppler ultrasonography}

After overnight fasting, Doppler ultrasonography was performed in the morning, under resting condition in the supine position. Since exercise causes reduction in CA blood flow. The entire ultrasonographic examination of abdomen was also done for any possible abnormal finding by B-mode ultrasonography in the supine position. None of the patients and the healthy controls had any hepatic or 
splenic diseases. Duplex Doppler examinations were performed using a Hitachi Vision device, equipped with $\mathrm{C} 5-2 \mathrm{MHz}$ transducer, by an experienced pediatric radiologist (M.B.O.) blinded to the endoscopy and histology results. The following Doppler variables were studied:

- Peak systolic velocity (PSV), representing maximum flow velocity recorded during each cardiac cycle,

- $\quad$ End diastolic velocity (EDV), the value recorded at the end of the cardiac diastole. EDV is related with end organ resistance.

- Pulsatility index (PI), related to impedance of the arterial bed and defined as $\mathrm{PI}=\mathrm{PSV}-\mathrm{EDV} / \mathrm{mean}$ velocity, and

- $\quad$ The resistive index (RI), which is again related to the impedance of the arterial bed and is calculated as described by Planilo et al (RI=PSV-EDV/S). PI and RI were automatically calculated by the microcomputer, a component of the duplex scanner.

\section{Statistical analysis}

Statistical analysis was performed using percentage distribution for qualitative data and median interquartile range (IQR) or mean (standard deviation) for quantitative data. For comparison between the two groups, Student's t-test for independent paired samples was used for variables showing normal distribution, and the Mann-Whitney U-test was used for those variables not distributed normally. The chisquare test was used to compare categorical variables. P-values less than 0.05 were considered statistically significant. Data was analyzed on SPSS 23.0 (SPSS Inc. Chicago, IL, United States) statistical software.

\section{Results}

Demographic findings and anthropometric measurements of the patients and healthy children are shown in Table 1. The patients' median age was 15 years (range: 9-17 years), median weight was $45.1 \mathrm{~kg}$ (range: $25-72 \mathrm{~kg}$ ), and the majority were female $(n=22,61.1 \%)$. Obese patients were not included in the study.

Table 1. Comparison of demographic findings and anthropometric measurements of the patients and healthy children

\begin{tabular}{llll}
\hline & Group 1 $(\mathbf{n}=\mathbf{3 6})$ & Group 2 $(\mathbf{n}=\mathbf{2 8})$ & $\boldsymbol{p}$ value \\
\hline Age, years & $14.4 \pm 2.9$ & $13.8 \pm 3.2$ & 0.43 \\
Gender, $\mathrm{n}(\%)$ & & \\
$\quad$ Male & $14(38.9)$ & $12(42.8)$ & 0.74 \\
$\quad$ Female & $22(61.1)$ & $16(57.2)$ & 0.24 \\
Body weight, $\mathrm{kg}$ & $46.3 \pm 13.2$ & $42.5 \pm 12.7$ & 0.50 \\
Body mass index, $\mathrm{kg} / \mathrm{m}^{2}$ & $18.6 \pm 3.0$ & $18.1 \pm 2.9$ & \\
\hline
\end{tabular}

Values are expressed as mean \pm standard deviation or number (\%)

Calculated for comparisons between groups using Student's t-test for continuous variables and the chi-square test for categorical variables

Celiac artery Doppler parameters in the patients and healthy children are shown in Table 2. Mean EDV and mean PSV were significantly higher in Group $2(54.42 \pm 9.37 \mathrm{~cm} / \mathrm{s}$ and $183.96 \pm 19.83 \mathrm{~cm} / \mathrm{s}$, respectively) than in Group $1(32.55 \pm 6.86 \mathrm{~cm} / \mathrm{s}$ and $139.89 \pm 14.91$ $\mathrm{cm} / \mathrm{s}$, respectively) $(p<0.001$ and $p<0.001$, respectively). In addition, mean $\mathrm{RI}$ and mean $\mathrm{PI}$ were significantly higher in Group $1(0.71 \pm 0.05$ and $1.82 \pm 0.22$ respectively) than in Group $2(0.60 \pm 0.07$ and $1.73 \pm 0.16$, respectively) $(p<0.001$ and $p=0.020$, respectively). Mean
RI was significantly higher and mean PSV significantly lower in group $1 \mathrm{~b}$ (moderate and severe gastritis group) $(0.73 \pm 0.04$ and $139.40 \pm 12.64 \mathrm{~cm} / \mathrm{s}$, respectively) than in group 1a (mild gastritis group) $(0.70 \pm 0.06$ and $140.64 \pm 18.42 \mathrm{~cm} / \mathrm{s}$, respectively) ( $p=0.045$ and $p=0.033$, respectively). Mean EDV was lower in group $1 \mathrm{~b}$ than in group $1 \mathrm{a}$, while mean PI was higher in group $1 \mathrm{~b}$ than in group $1 \mathrm{a}$. However, these differences were not statistically significant $(p>0.05)$. Mean PSV was significantly lower in group 1c (patients with $\mathrm{H}$. pylori) (138.31 \pm 12.49 
$\mathrm{cm} / \mathrm{s}$ ) than in group 1d (patients without $\mathrm{H}$. pylori) (140.52 \pm 17.60$)(p=0.040)$. Mean EDV was lower in group $1 \mathrm{c}$ than in group $1 \mathrm{~d}$, and mean $\mathrm{RI}$ and mean $\mathrm{PI}$ were higher in group $1 \mathrm{c}$ than in group 1d. However, these differences were also not statistically significant $(p>0.05)$ (Figure 1a, b, c, d, e).

Table 2. Doppler parameters of celiac artery in patients and healthy children

\begin{tabular}{cllll}
\hline Group & Mean PSV, cm/s & Mean EDV, cm/s & Mean RI & Mean PI \\
\hline 1 & $139.89 \pm 14.91$ & $32.55 \pm 6.86$ & $0.71 \pm 0.05$ & $1.82 \pm 0.22$ \\
2 & $183.96 \pm 19.83$ & $54.42 \pm 9.37$ & $0.60 \pm 0.07$ & $1.73 \pm 0.16$ \\
1a & $140.64 \pm 18.42$ & $34.00 \pm 7.53$ & $0.70 \pm 0.06$ & $1.78 \pm 0.24$ \\
1b & $139.40 \pm 12.64$ & $31.63 \pm 6.41$ & $0.73 \pm 0.04$ & $1.88 \pm 0.19$ \\
1c & $138.31 \pm 12.49$ & $31.52 \pm 6.85$ & $0.72 \pm 0.06$ & $1.82 \pm 0.13$ \\
1d & $140.52 \pm 17.60$ & $33.70 \pm 6.89$ & $0.70 \pm 0.05$ & $1.81 \pm 0.30$ \\
\hline
\end{tabular}

PSV, peak systolic velocity; EDV, end-diastolic velocity; RI, resistive index;

$\mathrm{PI}$, pulsatility index

Values are expressed as mean \pm standard deviation

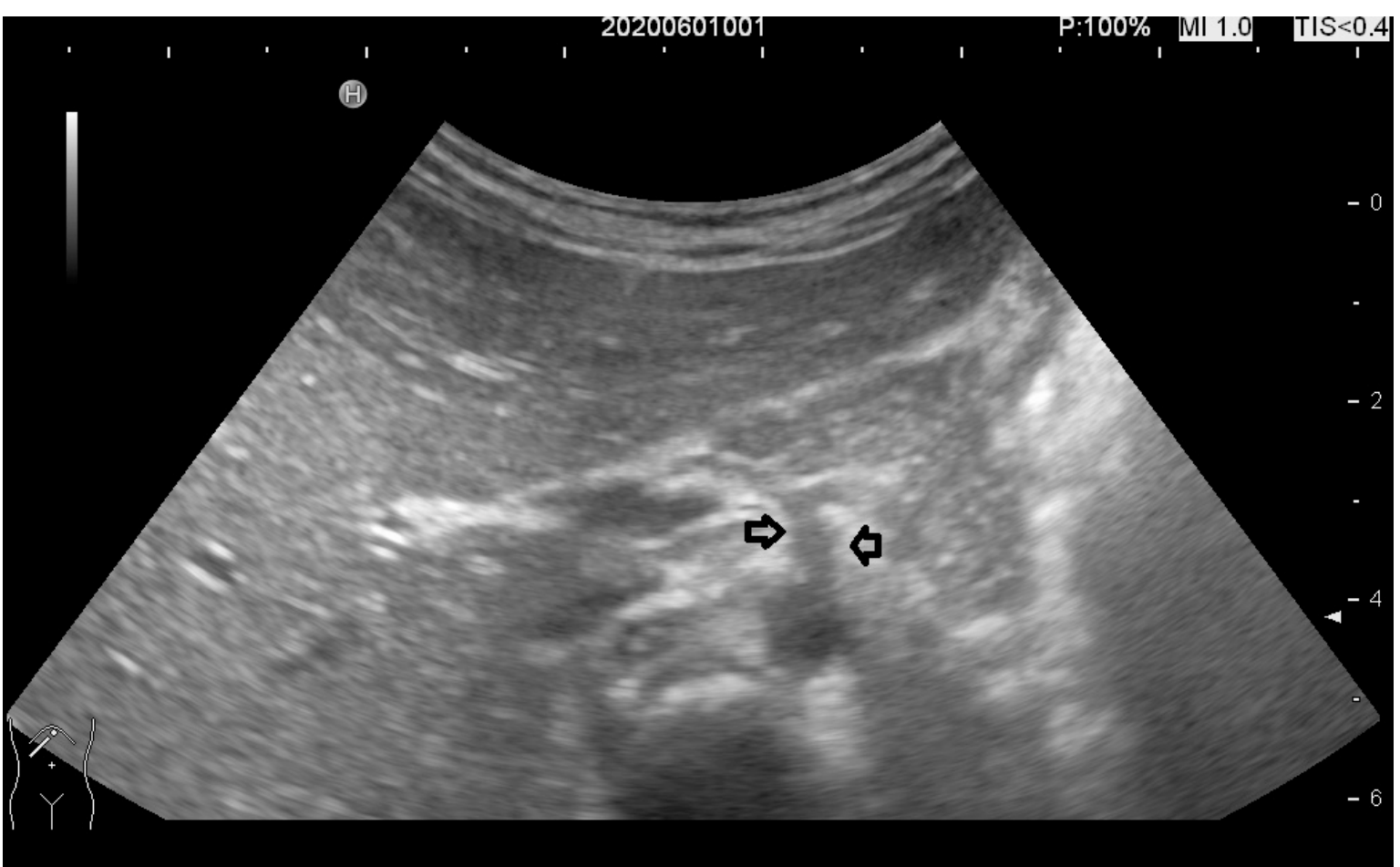

Figure 1a. The gray scale findings of celiac artery vessels which is shown by the black arrows 


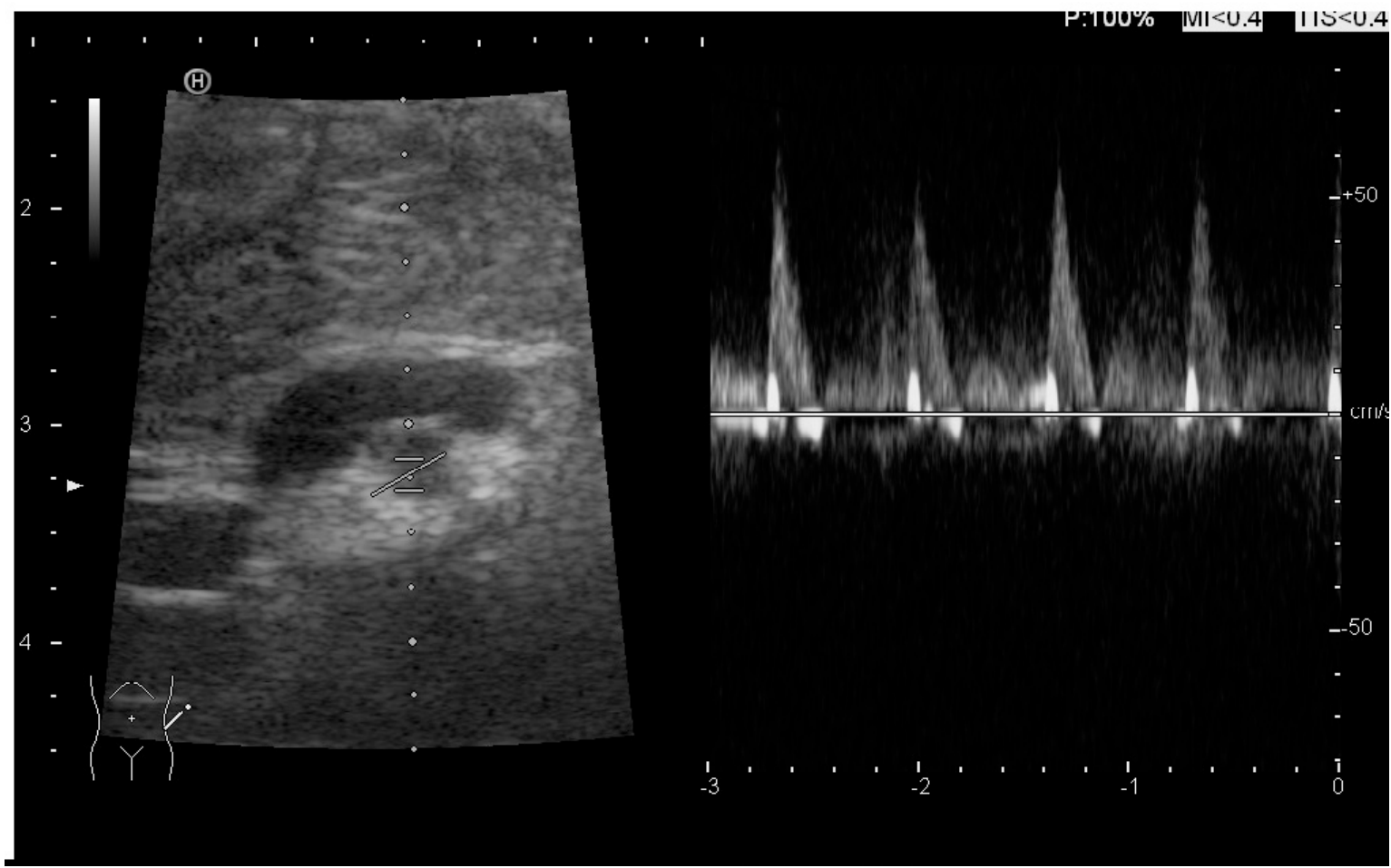

Figure 1b. Assessment of 9 year old healthy volunteer with the celiac values. The peak velocity was $52 \mathrm{~cm} / \mathrm{s}$

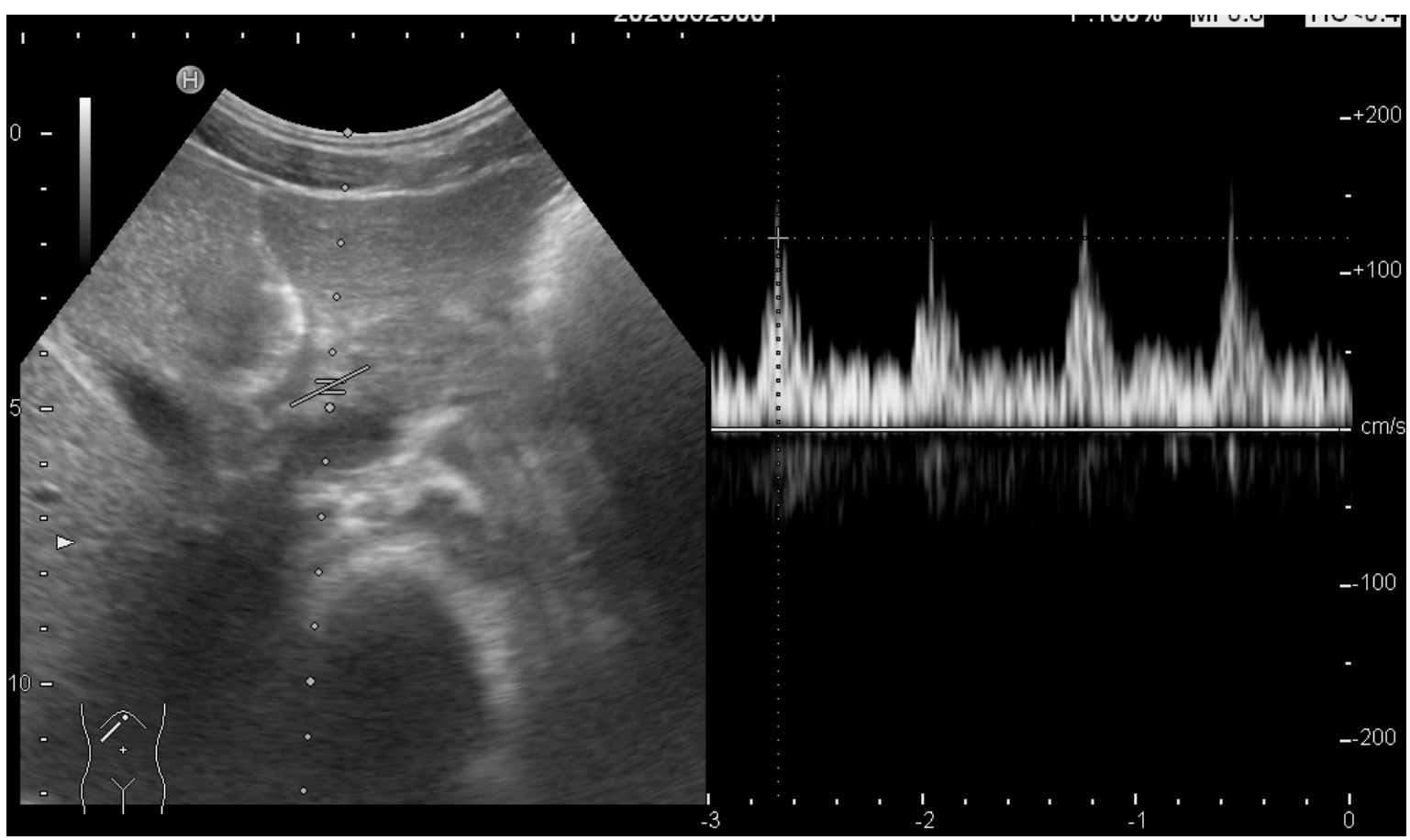

Figure 1c. Doppler examination of 12 year old male diagnosed with gastritis. The peak velocity reaches up to $125 \mathrm{~cm} / \mathrm{s}$ 


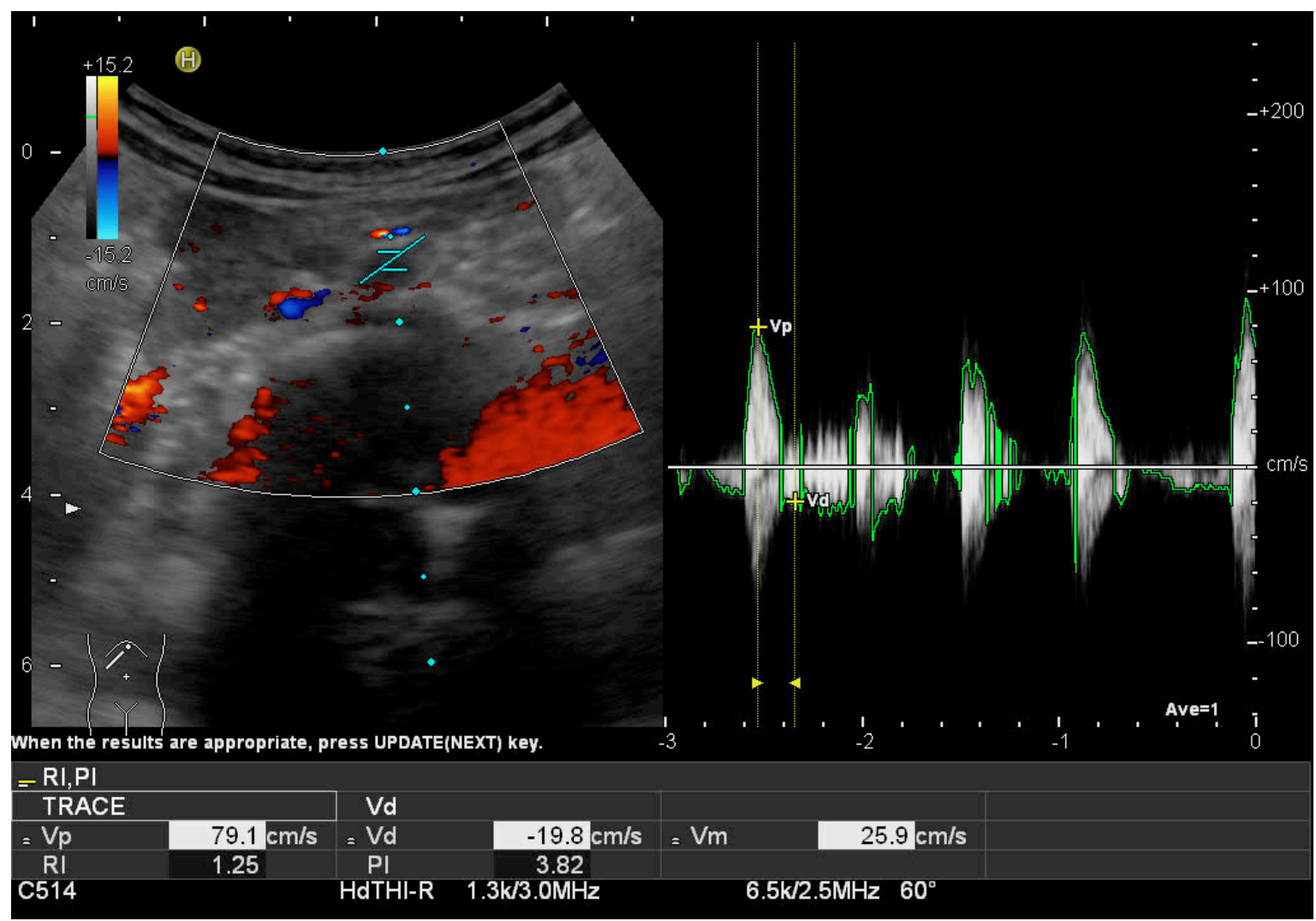

Figure 1d. Doppler examination of 8 year old male diagnosed with acute gastritis. The doppler values was get out of $\mathrm{PI}$ of 3,82 and $\mathrm{RI}$ of 1,25

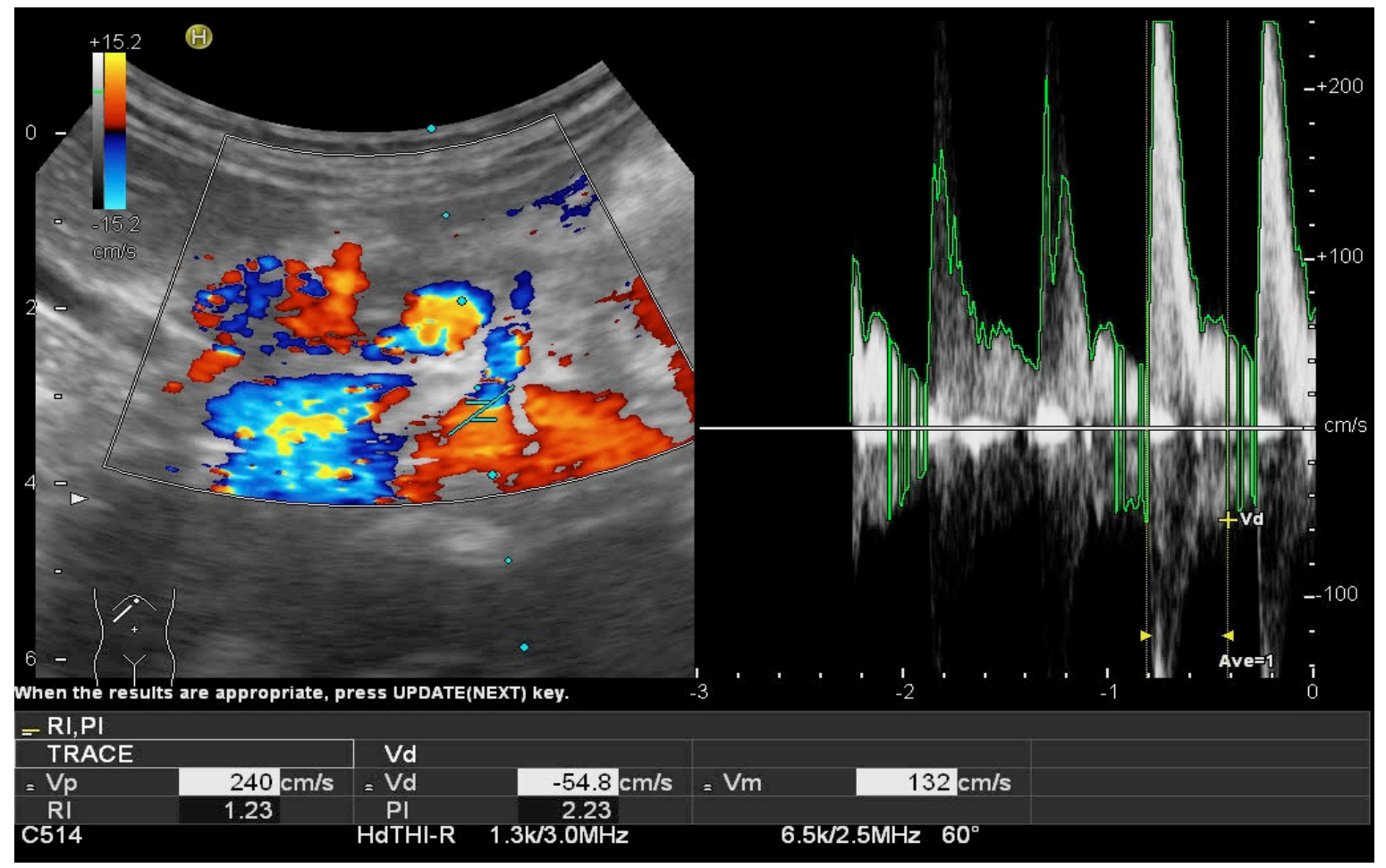

Figure 1e. Doppler examination of 9 year old male diagnosed with acute gastritis. The PI value was 2,23 and RI was 1,23. In these figures the PI corresponds to pulsatility index whereas RI stands for resistive index 


\section{Discussion}

Our findings revealed significantly lower mean PSV and EDV and higher mean RI and PI in children with gastritis compared to the control group. In contrast, significantly lower mean PSV was determined in group 1c $(\mathrm{H}$. pylori positivepatients) than in group $1 \mathrm{~d}(\mathrm{H}$. pylori-negative patients), and in group $1 \mathrm{~b}$ (patients with severe gastritis) compared to group 1a (patients with mild gastritis).

Some studies using various different methods (e.g. laser Doppler flowmeter) to investigate mucosal blood flow have reported decreased mucosal blood flow in patients with chronic gastritis and peptic ulcers [7, 11]. Koktener et al. [8] observed decreased CA blood flow in adult patients with endoscopically and histopathologically proven active chronic gastritis. Since there have been no previous pediatric studies in this area, this is the first research to evaluate CA blood flow in children with chronic gastritis. In agreement with previous adult studies, we also detected lower blood flow in $\mathrm{CA}$ in children with chronic gastritis.

Platelet activating factor (PAF) released from mast cells and some other inflammatory cells is a potent vasoconstrictor. PAF causes early leukocyte migration and hypoperfusionin gastrointestinal microcirculatory [12]. Although few mast cells can be seen in normal mucosa, the level increases in the presence of inflammation [13]. Mast cells had been detected in gastric mucosa of patients with chronic gastritis in some studies, the numbers increasing in line with the severity of gastritis [14]. Vascular resistance in the gastric mucosa therefore increases. These changes occurring in the gastric mucosa may reduce mucosal blood flow. The reduced flow rates in CA in this study may be due to increased vascular resistance in the gastric mucosa.

This study also revealed lower blood flow in the $\mathrm{CA}$ of patients with $\mathrm{H}$. pylori-positive chronic gastritis than in negative chronic gastritis. $\mathrm{H}$. pylori a gram negative bacterium had been shown to be associated with chronic gastritis and gastric malign diseases like gastric carcinoma and lymphoma. An association between $\mathrm{H}$. pylori infection and vascular diseases have also been suggested in some epidemiological studies. In the case of $\mathrm{H}$. pylori infection, after colonization, the organism can initiate the production and release of some proinflammatory cytokines. $\mathrm{H}$. pylori activates proiflammatory pathways like nuclear factor kappa B which results in expression of tumor necrosis factor alfa $[15,16]$. Inflammatory cytokines can cause functional and structural abnormalities in the arterial wall. This abnormalities occurs by different mechanisms like changes in serum lipid levels, and the metabolism and production of oxidative stress [17]. Atherosclerosis like vascular events have been reported in patients with $\mathrm{H}$. pylori infection [18, 19]. Judaki et al. [18] reported more prominent vascular changes in patients with $\mathrm{H}$. pylori-positive chronic gastritis than in $\mathrm{H}$. pylori-negative chronic gastritis. Some studies have also reported decreased gastric microcirculation in patients with $\mathrm{H}$. pylori infection $[12,20]$. These findings all show that both micro- and macrovascular changes occur in the presence of $\mathrm{H}$. pylori infection.

This study has some limitations. First, the study population was relatively small. Second, Doppler examination is highly operatordependent, its diagnostic quality being influenced by radiologist experience. Third, the presence of bowel gas and fecal material may compromise the diagnostic quality of Doppler examinations. Since patients older than nine years were included in this study, we were unable to evaluate the benefits of Doppler ultrasonography in a younger age group. In addition, since our patients were not obese, we were unable to evaluate the usefulness of ultrasound in obese patients.

In conclusion, our results demonstrate that hemodynamic changes occur in celiac artery in children with chronic gastritis. Duplex Doppler ultrasonography investigation of the CA may be helpful in diagnosis of chronic gastritis. This non-invasive and cheaper method may be applied to children so unnecessary endoscopic procedures may be prevented. Doppler ultrasound examination will also be helpful choosing the most appropriate subsequent diagnostic procedure. Evaluation of the remission or suspected relapses by Doppler ultrasonography of the CA in patients with chronic gastritis is subject of future studies, involving a large number of pediatric patients.

Conflict of interest: No conflict of interest was declared by the authors. 


\section{References}

1. Sierra D, Wood M, Kolli S, Felipez LM. Pediatric gastritis, gastropathy, and peptic ulcer disease. Pediatr Rev 2018;39:542-549. https://doi.org/10.1542/ pir.2017-0234

2. Lee EJ, Lee YJ, Park JH. Usefulness of ultrasonography in the diagnosis of Peptic ulcer disease in children. Pediatr Gastroenterol Hepatol Nutr 2019;22:57-62. https://doi.org/10.5223/pghn.2019.22.1.57

3. Akbulut UE, Emeksiz HC, Kocak FG, Livaoglu A. Diagnostic yield of esophagogastroduodenoscopy in children with chronic abdominal pain. Arch Med Sci 2018;14:74-80. https://doi.org/10.5114/ aoms.2017.67675

4. Thomson M, Tringali A, Dumonceau JM, et al. Paediatric gastrointestinal endoscopy: European Society for Paediatric Gastroenterology Hepatology and Nutrition and European Society of Gastrointestinal Endoscopy Guidelines. J Pediatr Gastroenterol Nutr 2017;64:133153. https://doi.org/10.1097/MPG.0000000000001408

5. Whittle BJ. The defensive role played by gastric microcirculation. Meth Find Exp Clin Pharmacol 1989;11:35-43.

6. Guslandi M. Mucosal blood flow and gastric protectioneffect of neurohormonal and pharmacological agents. Int J Clin Pharmacol Ther Toxicol 1986;24:143-147.

7. Guslandi M, Sorghi M, Tittobello A. Does Helicobacter pylori affect gastric microcirculation? Ital J Gastroenterol 1994;26:383-384

8. Koktener A, Turkay FGC, Erarslan E, et al. Doppler sonography of hemodynamic changes of the celiac artery in chronic active gastritis. Turk J Med Sci 2012;42:1273-1277. https://doi.org/10.3906/sag-12018

9. Dixon MF, Genta RM, Yardley JH, Correa P. Classification and grading of gastritis. The updated sydney system. International workshop on the histopathology of gastritis, Houston 1994. Am J Surg Pathol 1996;20:1161-1181. https://doi. org/10.1097/00000478-199610000-00001

10. Tytgat GNJ. The sydney system: endoscopic division. Endoscopic appearances in gastritis/duodenitis. J Gastroenterol Hepatol 1991;6:223-234. https://doi. org/10.1111/j.1440-1746.1991.tb01469.x

11. Wang $Y$, Yuan SY, Zhang ZY. A study of gastric mucosal blood flow of peptic ulcer, chronic gastritis and gastric carcinoma. Zhonhua Nei Ke Za Zhi 1993;32:239-242.

12. Henriksnas J, Atuma C, Phillipson M, Sandler S, Engstrand L, Holm L. Acute effects of Helicobacter pylori extracts on gastric mucosal blood flow in the mouse. World J Gastroenterol 2009;15:219-225. https://doi.org/10.3748/wjg.15.219
13. Moorchung N, Srivastava AN, Gupta NK, Malaviya AK, Achyut BR, Mittal B. The role of mast cells and eosinophils in chronic gastritis. Clin Exp Med 2006;6:107-114. https://doi.org/10.1007/s10238-0060104-9

14. Caruso RA, Parisi A, Crisafulli C, et al. Intraepithelial infiltration by mast cells in human Helicobacter pylori active gastritis. Ultrastruct Pathol 2011;35:251-255. https://doi.org/10.3109/01913123.2011.606964

15. Hu Y, Liu JP, Zhu Y, Lu NH. The Importance of toll-like receptors in NF-KB signaling pathway activation by Helicobacter pylori infection and the regulators of this response. Helicobacter 2016;21:428-440. https://doi. org/10.1111/hel.12292

16. Rahmani A, Moradkhani A, Ahmadi MRH, et al. Association between serum levels of high sensitive C-reactive protein and inflammation activity in chronic gastritis patients. Scand J Gastroenterol 2016;51:531537. https://doi.org/10.3109/00365521.2015.1102318

17. GimbroneJr MA, García Cardeña G. Endothelial cell dysfunction and the pathobiology of atherosclerosis. Circ Res 2016;118:620-636. https://doi.org/10.1161/ CIRCRESAHA.115.306301

18. Judaki A, Norozi S, Ahmadi MRH, Ghavam SM, Asadollahi K, Rahmani A. Flow mediated dilation and carotid intima media thickness in patients with chronic gastritis associated with Helicobacter pylori infection. Arq Gastroenterol 2017;54:300-304. https://doi. org/10.1590/S0004-2803.201700000-39

19. Lee M, Baek H, Park JS, et al. Current Helicobacter pylori infection is significantly associated with subclinical coronary atherosclerosis in healthy subjects: a crosssectional study. PLoS One 2018;13:e0193646. https:// doi.org/10.1371/journal.pone.0193646

20. Atuma C, Engstrand L, Holm L. Helicobacter pylori extracts reduce gastric mucosal blood flow by a nitric oxide-independent but mast cell- and plateletactivating factor receptor-dependent pathway in rats. Scand J Gastroenterol 1999;34:1183-1189. https://doi. org/10.1080/003655299750024689

Bu makale 03-05 Ekim 2019 tarihinde Trabzon'da düzenlenen 1. Karadeniz Pediatri Günleri'nde sözel bildiri olarak sunulmuştur.

Ethics committee approval: Ethics committee of Antalya Education and Research Hospital; data: 30.05.2019, number: 14/21)

\section{Author contributions}

U.E.A., M.B.O. constructed the main purpose and hypothesis of the study. U.E.A., M.B.A. developed the theory and arrangement the materials and methods section.Analysed the data in the results section with U.E.A., M.B.O. The discussion section of this article 
was written by U.E.A., I.A.I., revised, made the required corrections and confirmed by A.A. In addition, all authors discussed the whole study and confirmed final version. 